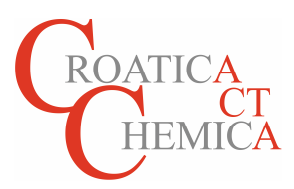

\title{
Professor Nenad Trinajstić - a Strong Supporter of Young Researchers
}

\author{
On the occasion of the $80^{\text {th }}$ Anniversary of Prof. Dr. Nenad Trinajstic \\ by Bono Lučić \\ NMR Center, Ruđer Bošković Institute, P.O. Box 180, HR-10002 Zagreb, Croatia
}

D URING the period of 25 years I have been working with Professor Trinajstić I have had many opportunities to witness and also to take part in Professor's meetings and conversations with new colleagues. Without exception those were young people with a keen interest in sciences and a strong desire to make their own original contribution to the overall opus of knowledge by carrying out scientific research and proving or refuting various hypotheses. Professor Trinajstićs strong disposition toward helping these young people (either directly, by helping them obtain research grants and find junior research appointments or, if such help was not available at the time, through an informal support) has always fascinated, both me and the few of my closest colleagues, deeply. His enthusiasm for working with and helping young people entering sciences has been his unwavering disposition throughout the time I have spent with Professor Trinajstić.

After the publication of my personal views of Professor Nenad Trinajstić in the foreword of special issue dedicated to his scientific jubilee (B. Lučić and M. V. Putz, Int. J. Chem. Model. 2014, 6, 167-175), I posed myself a question: Was Professor Trinajstić like this earlier in his career and in his other dealings with his students and young collaborators of which I had no first-hand knowledge? So I did a little research and over the past two years I've "interviewed" a number of my colleagues asking the same questions pertaining to Professor Trinajstić's disposition to his junior coworkers; I have found that all of my colleagues had arrived at an almost identical opinion. The last example would be the contribution of Dr. Predrag-Peter Ilich, a former PhD student of Professor Nenad Trinajstić, who expressed very similar impressions about the time and work with him in the reminiscence contributed to this special issue ("Celebrating my Ph.D. Thesis Mentor Birthday").

My experience - shared by many of my colleagues has been that anyone who knocked on the door of his office and professed an interest in doing research, even when bringing undeveloped and less than concrete ideas about that research, has found an enthusiastic Professor Trinajstic who would give ample advice and even help in developing a clearer and better defined research plan. Many times it was the case that the proposed research idea of a younger colleague was not closely-related to chemistry, and even that some of his students had very different educational background (like me). However, Professor Trinajstić, with his rare ability to see beyond the seemingly obvious limitations, would help this young colleague to turn their initial disadvantage around and to devise and define a novel and promising research plan. Perhaps the way in which Professor Trinajstić viewed and carried out his own scientific work, and the achievements that came from that work, were the basis for the emergence and consolidation of his belief/thesis - that chemistry is a central science. Along this line, Professor Trinajstić has for a longer time been debating this topic with other scientists and colleagues from the field of physics and biology and always strongly underwriting the validity of that thesis. So, because of central position of chemistry, chemical research should connect different disciplines, and also involve researchers from different fields.

An additional outstanding characteristic of Professor Nenad Trinajstić has been his leadership and mentorship in scientific research: he has been visibly interested in work progress, delighted by the new research ideas of young colleagues, and he never missed to give them recognition for 
the achieved results. Such a (daily) research and educational practice of Professor Trinajstić has always been stimulating to young people, valuable to them in the same way as the Professor Trinajstić's efforts in creating and providing opportunities for their research work and self-realization. I have been thinking about it and concluded that the efforts in encouraging and assisting in the development of young scientists are extremely wise educational activities, and that this act of continuous and selfless giving must in the long run acquire a strong meaning of its own. I think so because of the fact that whatever our future will be (in general and in scientific sense) it will be created and outlined by those who are young today. Therefore, if we help today's young people to become brave, good, and optimistic, it is highly probable that we will be able to look forward from the present time with optimism.

In recent years we have witnessed large and sustained efforts by European Union leaders in creating and providing employment opportunities for young people. Professor Trinajstić, by his educational and scientific research contributions and by his whole career, has been acting in the same spirit already for many decades.

Many students who have been successfully working with Professor Trinajstić over the years remember him as very passionate about his own work, productive, and highly cited researcher. Because of this I have collected, as a birthday present, (almost) all of his citation in the Web of Science on October 26, 2016. The total number of citations of $\mathbf{6 0 2}$ references (including monographs and books) authored or co-authored by Nenad Trinajstić was 18697, $\mathrm{h}$-index $=\mathbf{5 5}$. It is also interesting to note that his book Chemical Graph Theory (CRC Press, Boca Raton, Florida, both editions: 1983 and 1992) was cited 2466 times. In supplementary Table S1 are given the twenty most cited papers (cited, altogether, $\mathbf{4 6 8 8}$ times) co-authored by Nenad Trinajstić. His most cited paper (I. Gutman, M. Milun and N. Trinajstić, J. Am. Chem. Soc. 1977, 99, 1692-1704) had $\mathbf{5 5 5}$ citations as of October 26, 2016.

In the last 25 years my impression about Professor Nenad Trinajstić, and also the impression of the colleagues I have talked to about it, have been that he is a pleasant, positive, optimistic person, and an inspirational educator and researchers, constantly ready to help and give valuable advice to all (especially young) collaborators, encouraging them to define and realize novel research ideas. Thank you very much, dear Professor Trinajstić, for your constant help and advice during the past 25 years of our fruitful collaboration. I wish you, in my name and on behalf of all colleagues I know and who have been working with you, a happy $80^{\text {th }}$ birthday, good health and a success in realizing many more stimulating research ideas in future, which will likely be an inspiration to us and to other researchers in the field. 


\title{
Supplementary Material
}

\section{Professor Nenad Trinajstić - a strong supporter of young researchers}

\author{
Bono Lučić \\ NMR Center, Ruđer Bošković Institute, P.O. Box 180, HR-10002 Zagreb, Croatia
}

Table S1. Twenty most cited papers co-authored by Professor Nenad Trinajstić according to Web of Science (date: October 26, 2016).

\begin{tabular}{|c|c|c|}
\hline No. & Reference & Citations \\
\hline 1 & $\begin{array}{l}\text { I. Gutman, M. Milun and N. Trinajstić, "Graph Theory and Molecular Orbitals. XIX. Non-Parametric } \\
\text { Resonance Energies of Arbitrary Conjugated Systems", J. AM. CHEM. SOC. 99, 1692-1704 (1977). }\end{array}$ & 555 \\
\hline 2 & $\begin{array}{l}\text { I. Gutman and N. Trinajstić, "Graph Theory and Molecular Orbitals. III. Total } \pi \text {-Electron Energy of } \\
\text { Alternant Hydrocarbons", CHEM. PHYS. LETT. 17, 535-538 (1972). }\end{array}$ & 476 \\
\hline 3 & $\begin{array}{l}\text { D. Bonchev and N. Trinajstić, "Information Theory, Distance Matrix, and Molecular Branching“, } \\
\text { J. CHEM. PHYS. 67, 4517-4533 (1977). }\end{array}$ & 458 \\
\hline 4 & $\begin{array}{l}\text { I. Gutman, B. Ruščić, N. Trinajstić and C.F. Wilcox, Jr., "Graph Theory and Molecular Orbitals. XII. } \\
\text { Acyclic Polyenes", J. CHEM. PHYS. 62, 3399-3405 (1975). }\end{array}$ & 385 \\
\hline 5 & $\begin{array}{l}\text { Z. Mihalić and N. Trinajstić, "A Graph-Theoretical Approach to Structure-Property Relationships", } \\
\text { J. CHEM. EDUC. 69, 701-712 (1992). }\end{array}$ & 267 \\
\hline 6 & $\begin{array}{l}\text { S. Nikolić, G. Kovačević, A. Miličević and N. Trinajstić, “The Zagreb Indices } 30 \text { Years After”, } \\
\text { CROAT. CHEM. ACTA 76, (2003) 113-124. }\end{array}$ & 289 \\
\hline 7 & $\begin{array}{l}\text { D. Amić, D. Davidović-Amić, D. Bešlo and N. Trinajstić, "Structure-Radical Scavenging Activity } \\
\text { Relationship of Flavonoids", CROAT. CHEM. ACTA 76, (2003) 55-61. }\end{array}$ & 255 \\
\hline 8 & $\begin{array}{l}\text { A. Graovac, I. Gutman, N. Trinajstić and T. Živković, "Graph Theory and Molecular Orbitals. } \\
\text { Application of Sachs Theorem", THEORET. CHIM. ACTA 26, 67-78 (1972). }\end{array}$ & 229 \\
\hline 9 & $\begin{array}{l}\text { A. Sabljić and N. Trinajstić, "Quantitative Structure-Activity Relationships: The Role of Topological } \\
\text { Indices", ACTA PHARM. JUGOSL. 31, 189-214 (1981). }\end{array}$ & 203 \\
\hline 10 & $\begin{array}{l}\text { D. Plavšić, S. Nikolić, N. Trinajstić and Z. Mihalić, "On the Harary Index for the Characterization of } \\
\text { Chemical Graphs", J. MATH. CHEM. 12, 235-250 (1993). }\end{array}$ & 201 \\
\hline 11 & $\begin{array}{l}\text { S. Nikolić, N. Trinajstić and Z. Mihalić, "The Wiener Index: Development and Applications”, } \\
\text { CROAT. CHEM. ACTA 68, 105-129 (1995). }\end{array}$ & 182 \\
\hline 12 & $\begin{array}{l}\text { M.J.S. Dewar and N. Trinajstić, "Ground States of Conjugated Molecules. XX. SCF MO Treatment of } \\
\text { Compounds Containing Bivalent Sulphur", J. AM. CHEM. SOC. 92, 1453-1459 (1970). }\end{array}$ & 171 \\
\hline 13 & $\begin{array}{l}\text { Z. Mihalić, S. Nikolić and N. Trinajstić, "Comparative Study of Molecular Descriptors Derived from } \\
\text { the Distance Matrix", J. CHEM. INF. COMPUT. SCI. 32, 28-37 (1992). }\end{array}$ & 161 \\
\hline 14 & $\begin{array}{l}\text { Z. Mihalić, D. Veljan, D. Amić, S. Nikolić, D. Plavšić and N. Trinajstić, "The Distance Matrix in } \\
\text { Chemistry", J. MATH. CHEM. 11, 223-258 (1992). }\end{array}$ & 135 \\
\hline 15 & $\begin{array}{l}\text { B. Lučić and N. Trinajstić, "Multivariate Regression Outperforms Several Robust Architectures of } \\
\text { Neural Networks in QSAR Modeling", J. CHEM. INF. COMPUT. SCI. 39, 121-132 (1999). }\end{array}$ & 127 \\
\hline 16 & $\begin{array}{l}\text { D. Amić, D. Amić-Davidović, D. Bešlo, V. Rastja, B. Lučić and N. Trinajstić, "SAR and QSAR of the } \\
\text { Antioxidant Activity of Flavonoids", CURR. MED. CHEM. 14, 827-845 (2007). }\end{array}$ & 126 \\
\hline 17 & $\begin{array}{l}\text { D. Bonchev, O. Mekenyan and N. Trinajstić, "Isomer Discrimination by Topological Information } \\
\text { Approach", J. COMPUT. CHEM. 2, 127-148 (1981). }\end{array}$ & 125 \\
\hline 18 & $\begin{array}{l}\text { M.J.S. Dewar, J.A. Hashmall and N. Trinajstić, "Ground States of Conjugated Molecules. XXII. } \\
\text { Polarographic Reduction Potentials of Hydrocarbons", J. AM. CHEM. SOC. 92, 5555-5559 (1970). }\end{array}$ & 118 \\
\hline 19 & $\begin{array}{l}\text { M.J.S. Dewar and N. Trinajstić, "Semiempirical SCF MO Treatment of Excited States of Aromatic } \\
\text { Compounds", J. CHEM. SOC. A. 9, 1220-1237 (1971). }\end{array}$ & 117 \\
\hline 20 & $\begin{array}{l}\text { B. Lučić, N. Trinajstić, S. Sild, M. Karelson and A.R. Katritzky, “A New Efficient Approach for } \\
\text { Variable Selection Based on Multiregression: Prediction of Gas Chromatographic Retention Times } \\
\text { and Response Factors", J. CHEM. INF. COMPUT. SCI. 39, 610-621 (1999). }\end{array}$ & 108 \\
\hline
\end{tabular}

